\title{
High-Resolution Electrical Resistivity Tomography (ERT) to Characterize the Spatial Extension of Freshwater Lenses in a Salinized Coastal Aquifer
}

\author{
Nicolas Greggio ${ }^{1}$, Beatrice M. S. Giambastiani ${ }^{2, *(\mathbb{D})}$, Enrico Balugani ${ }^{1}$, Chiara Amaini ${ }^{3}$ \\ and Marco Antonellini 2 (D) \\ 1 CIRI EA-Interdepartmental Centre for Industrial Research on Energy and Environment, University of Bologna, \\ 48123 Ravenna, Italy; nicolas.greggio2@unibo.it (N.G.); enrico.balugani2@unibo.it (E.B.) \\ 2 BIGEA-Biological, Geological, and Environmental Sciences, University of Bologna, 40126 Bologna, Italy; \\ m.antonellini@unibo.it \\ 3 CIRSA-Interdepartmental Research Centre for Environmental Sciences, 48123 Ravenna, Italy; \\ chiara.amaini@studio.unibo.it \\ * Correspondence: beatrice.giambastiani@unibo.it; Tel.: +39-0544-937318
}

Received: 26 July 2018; Accepted: 8 August 2018; Published: 10 August 2018

\begin{abstract}
High-resolution electrical resistivity tomography (ERT) with electrode spacing of $1 \mathrm{~m}$ proved to be an effective methodology to characterize ephemeral, sparse, and discontinuous freshwater lenses within the almost completely salinized shallow aquifer of the low coastal zone near Ravenna. ERT profiles with a vertical resolution of $0.25-0.5 \mathrm{~m}$, once calibrated with groundwater data (water table depth and electrical conductivity) collected in multi-level sampler systems at the same spatial resolution, are reliable and provide repeatable measurements in time. The ERT methodology allows for fast data acquisition over large areas and it also permits the study of the evolution in time of freshwater availability in coastal zones, which is important for local ecosystems and soil resources. This makes high-resolution ERT a valid tool to aid local stakeholders and decision makers to effectively manage freshwater lenses, and guarantee their preservation or augmentation by means of managed aquifer recharge.
\end{abstract}

Keywords: high resolution electrical resistivity tomography (ERT); coastal aquifer; freshwater lenses; salinization; dune

\section{Introduction}

In many coastal areas worldwide, freshwater lenses within dunes are the only freshwater resources available [1,2]. These freshwater resources are often relatively small, but crucial to both the ecosystem and human activities [3,4]. In the coastal zone, the interaction between saltwater entering the aquifer from the sea and freshwater is described by the Ghyben-Herzberg theory (GHT, [5,6]). When rainwater infiltrates the soil it accumulates on top of the saline groundwater; the GHT states that the thickness of the freshwater lens is directly related to the elevation of the water table above the sea level [2]. In low elevation coastlines like in the Netherlands or the Po Valley in Italy, thin freshwater lenses can develop under the coastal dune system [7]. These thin freshwater lenses sustain plant life in an otherwise very saline environment [4]; the resulting vegetation cover allows the development of unique and complex ecosystems [8] and the stabilization of dunes [9].

Various studies have shown the development, persistence and dynamics of coastal freshwater lenses using both direct (boreholes and sampling) and indirect (geophysics) methods and they have highlighted their vulnerability to salinization, especially in semiarid and arid areas $[1,2,7,10-13]$. Seasonal and daily fluctuations in the transition surface due to periodic variations in precipitation and sea level result in salt dispersion and diffusion in the freshwater lenses, constantly changing their 
thickness and increasing the brackish water mixing zone width $[1,7,10]$. In addition, the climate change effect on precipitation amounts and patterns, as well as the increase in mean sea level, will reduce the coastal freshwater resources, threatening the local ecosystems and human activities [14].

Freshwater lenses can be directly monitored through piezometers by sampling groundwater at different depths (piezometer clusters, multi-level samplers). This methodology gives point measurements, continuous in time but limited in space $[1,13,15]$. Cluster-type piezometers with short-spaced filters allow groundwater sampling at fixed depths and detailed vertical discretization of chemical and physical parameters. This, however, may be inadequate in the case of thin freshwater lenses with marked seasonal dynamics [1]; piezometers with filters at specific depths are not adequate to represent the lenses dynamics over time. Furthermore, the high level of interpolation and extrapolation needed to estimate the freshwater resources from point measurements increases the overall uncertainty of the results. The geophysical methods are generally cheaper and less invasive [11,16]. The vertical electrical sounding (VES) geophysical method has been successfully used in freshwater studies [2,7]. However the VES is a one-dimensional (1D) measurement technique, and is thus prone to high uncertainty when interpolated. De Louw et al. [7] used helicopter-borne electromagnetic measurements in order to better define the spatial extent of freshwater lenses; the technique, though, is very expensive.

The electrical resistivity tomography (ERT) method was successfully applied to the spatial characterization of saltwater intrusion in coastal areas [12,17-20], but has not yet been used to map thin freshwater lenses. ERT is especially useful wherever a network of boreholes, piezometers, and direct sampling of groundwater are available [21,22]. The point measurements are useful to calibrate the ERT method that is then used to create a series of two-dimensional images of freshwater-saltwater distribution in the aquifer [19].

The aim of this study is to assess the effectiveness and resolution of the ERT method to observe and characterize thin (thickness $<1-2 \mathrm{~m}$ ) dynamic freshwater lenses in a salinized coastal dune aquifer below an area with low topography and semiarid climate. The climate conditions occurring before and during the survey periods are considered, because they directly affect freshwater lens development. Cozzolino et al. [13] used a network of multi-level samplers (MLS) and piezometers to observe freshwater lenses stored in the coastal dunes of Ravenna and study their buffer effect on groundwater salinization. In the same area we applied the ERT method with 1-m electrode spacing in order to map the spatial extent and thickness of freshwater lenses. For the aim of the paper, high-resolution ERT means a survey with a resolution below $0.2 \mathrm{~m}$ that is in contrast to the traditional resolution adopted in hydrogeological studies (ranging above 1-2 m) [12,17-20]. The resolution is obtained applying to the electrode spacing the rule of thumb that defines the depth of investigation as $\mathrm{L} / 5$, where $\mathrm{L}$ is the ERT length [23]. Therefore, for an electrode spacing ranging at $0.5-1 \mathrm{~m}$, as adopted here, the resolution is $<0.2 \mathrm{~m}$. Studies with similar high resolution are rare in literature and only Wilkinson et al. [24] performed continuous ERT surveys with comparable resolution.

We used available lithology and groundwater data obtained from auger holes and multi-level sampler piezometers to elaborate, interpret and validate the ERT data.

\section{Study Area}

The study area is located near Ravenna (south of the Po river delta, Italy; Figure 1) and includes the last untouched and well preserved coastal dunes and pinewood, called 'Ramazzotti'. Prior to the fire that destroyed the majority of the forest in July 2012, the area was dominated by Pinus Pinaster, which was planted starting from the end of the 19th century to stabilize the sand and protect agricultural and reclaimed land from marine spray. Today the area is part of the Delta Po River Park and classified as a 'Special Protected Area' [25] and 'Site of Community Importance' [26], as well as a Ramsar site [27]. As it is part of the Delta Po River Park and because of its relevant biodiversity, the access to the area is currently limited to the public and only permitted to scientists and researchers. Thus, no direct anthropogenic modifications are currently affecting the area. 


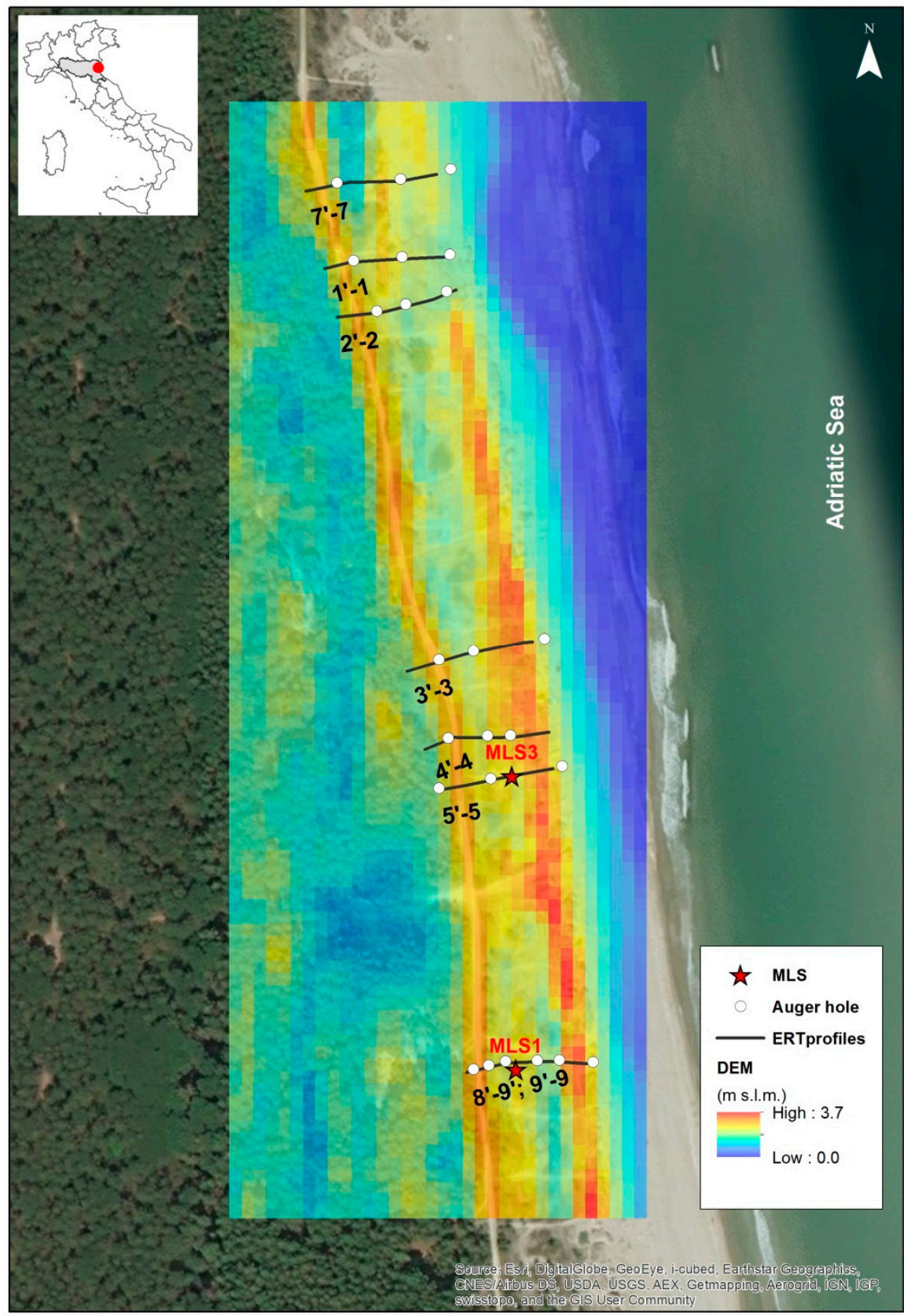

Figure 1. Study area location. The digital elevation model (DEM), electrical resistivity tomography (ERT) profiles, multi-level sampler piezometers (MLSs), and auger hole locations are also shown.

The pine forest extends parallel to the coast for 150 ha. Due to a low topography (average elevation is about 0.3-0.5 m mean sea level (m.s.1.)), a high rate of natural and anthropic subsidence [28,29], an extensive drainage system that controls water table depth (WTD) across the pine forest and in the agricultural crops, the coastal aquifer contains only brackish to saline groundwater. Freshwater lenses are limited in areal extent, thickness, and time, and are related to dune heights [13]. Where present, these lenses are important to reduce water and soil salinization, which in turn control the health of the whole coastal ecosystem [4]. Another factor affecting freshwater lens size in the coastal aquifer (not in the investigated area) is the current strong fragmentation of the dune system. In the 1950s the Ravenna coastline was characterized by continuous and well-preserved dune belts, which were gradually flattened and fragmented to make room for tourism facilities [30], thus increasing coastal vulnerability to storms and erosion [31]. More details about general description, hydrogeological 
setting, and the natural and anthropogenic factors affecting the entire Regional coastal zone and freshwater lens presence are further described in Cozzolino et al. [13] and Giambastiani et al. [32,33].

\section{Hydrogeological Setting}

The shallow coastal unconfined aquifer extends from the coast to 6-7 km inland, with a thickness ranging from $12 \mathrm{~m}$ westward to $25 \mathrm{~m}$ eastward. It consists of two medium-fine sandy units (transgressive barrier sand from the top to $-7 \mathrm{~m}$ m.s.l., and beach-ridge deposits at -23 to $-25 \mathrm{~m} \mathrm{~m} . \mathrm{s} .1$.) separated by shallow-marine deposits consisting of alternations of silt, clay, and fine sand layers [34]. The Pleistocene alluvial plain deposits, consisting of impermeable clay, act as a bottom-confining layer (aquifer basement) at about $-25--30 \mathrm{~m}$ m.s.l. [35]. The saturated thickness of the aquifer investigated in this study was approximately 6-7 m, down to the top of the prodelta unit, which acts as an aquitard unit especially in proximity to the sea. It is within this depth that the freshwater lenses are present in the current coastal setting [13]. The coastal dune system is the main recharge area where rainfall infiltrates and percolates to the saturated zone recharging groundwater.

\section{Materials and Methods}

\subsection{ERT Surveys}

Between July and December 2014, eight two-dimensional (2D) electrical resistivity tomography (ERT) surveys were carried out across the beach-dune system (Figure 2), perpendicular to the coastline, as shown in Figure 1.
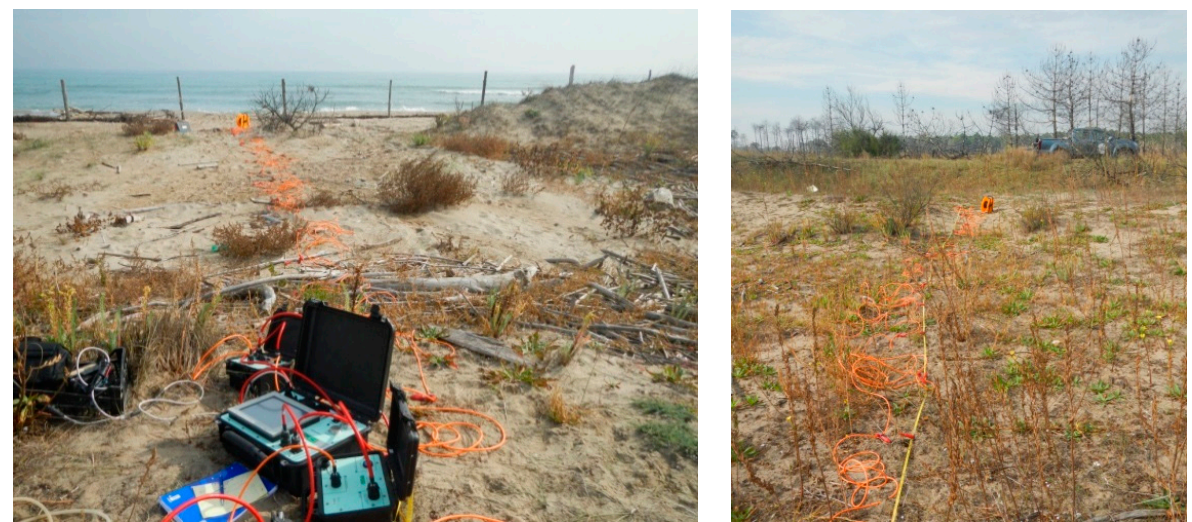

Figure 2. Examples of operating field equipment and study area.

Each resistivity profile consisted of two lines of 32 electrodes, with 1-m spacing, an overlap of 16 electrodes, and a total length of $48 \mathrm{~m}$. The ERT electrode spacing influences the maximum investigation depth observed and the vertical resolution. The most common electrode spacing used in saltwater intrusion studies was $5 \mathrm{~m}$, corresponding to vertical resolution of about $1 \mathrm{~m}$ [36]. This resolution would be inadequate to observe and characterize the thin $(\sim 1 \mathrm{~m})$, dynamic freshwater lenses that characterize the studied aquifer. Based on this, the selected electrode-spacing allowed about $5 \mathrm{~m}$ of investigation depth and $<0.5 \mathrm{~m}$ of vertical resolution (corresponding to about 9 nodes $/ \mathrm{m}^{2}$ ), appropriate to identify the shallow WTD and to discriminate freshwater lenses from brackish-saline groundwater. Only profile 9 (Figure 1) was repeated in December 2014 by decreasing the electrode spacing to $0.5 \mathrm{~m}$, thus allowing a greater vertical resolution $(0.25 \mathrm{~m})$ to the detriment of investigation depth (about 2-2.5 m). In order to have the same spatial coverage of the other profiles (48 $\mathrm{m}$ ), five lines of 32 electrodes were required in this case, again with an overlap of 16 electrodes.

Apparent resistivity measurements were acquired using a P.A.S.I. Electrical Imaging System Mod. 16G-N (PASI srl, Torino, Italy). For all ERT profiles a Wenner electrode configuration $(\mathrm{AM}=\mathrm{MN}=\mathrm{NB}$ 
$=\mathrm{a}=1 \mathrm{~m}$ and 0.5 -m electrode spacing) was used [37]. RTK-GPS topographic surveys were carried out along the ERT surveys.

The real resistivities obtained in the field were inverted to obtain a model of subsurface resistivity, which approximates the real subsurface resistivity distribution. The least-squared inversion was done using specific RES2DINV resistivity and induced polarization interpretation software as described by GEOTOMO [38]. Bad datum points and points with root mean square error (RMSE) higher than 60 or $80 \%$ were removed from the final inversion.

Topographic data were included in the model display by choosing the distorted finite-element grid with damped distortion. With this arrangement, model blocks are damped, and deep grid nodes are shifted to a lesser extent than surface nodes, i.e., the effect of topography is "damped" with depth.

Due to the large resistivity contrasts of 500-1 $\Omega \mathrm{m}$, the mesh was refined to four nodes between adjacent electrodes in order to improve the inversion results. Data noise reduction was obtained by inversion via a smoothness-constrained least square method [39] where the block's resistivity values (model parameters) were adjusted iteratively to obtain a realistic distribution of resistivity (model response). The difference between calculated and measured resistivity values in the model was given by the root mean squared (RMS) error method. However, it has to be noted that the model with the lowest RMS error is not always the most appropriate as it can induce unrealistic variations in the resistivity interpretation that may not always be the "best" representation of the geological setting. The most conservative approach was used in this case, by accepting the model with $3-5$ iterations after the absolute error no longer significantly changed [38].

The RES2DINV software automatically assigned chromatic scales from the resistivity range of the selected profile. This did not permit us to compare profiles with different resistivity ranges and thus chromatic scales. For this reason, we decided to use groundwater monitoring data (WTD and salinity; see following section) and literature data [12,40-42] to define hydrogeological limits and standardize the chromatic scales.

\subsection{Hydrological Data}

Two multi-level sampler piezometers (MLS, [15]), installed close to the ERT survey locations (Figure 1) were used for groundwater monitoring and sampling. Each MLS has five mini-filters; the first five are $0.5-\mathrm{m}$ apart and the last three are 1-m apart, down to a maximum depth of 5-6 $\mathrm{m}$. The MLS is also equipped with an independent $0.06-\mathrm{m}$-diameter piezometer for water-level measurement. Filter depths were determined at the time of instrumentation assembly with the aim of monitoring the freshwater-saltwater interface, which in this area lies between -2 and $-4 \mathrm{~m} \mathrm{~m} . s .1$. (figure of instrumentation in [13]). The MLS are located at about 50 and $100 \mathrm{~m}$ from the coastline. The WTD (m m.s.l.), electrical conductivity $(\mathrm{EC})(\mathrm{mS} / \mathrm{cm})$, and temperature $\left({ }^{\circ} \mathrm{C}\right)$, were monitored at the same time as the eight ERT campaigns by water level loggers and multi-parametric probes. Moreover, a total of 27 auger holes were drilled along the ERT profiles during the survey in order to compare WTD and electrical conductivity directly measured with the ones obtained by ERT elaboration. Water levels were converted into equivalent freshwater heads by the method reported in Post et al. [43], taking into account groundwater variable density.

Groundwater salinity was classified based on EC values into: freshwater (EC $<3 \mathrm{mS} / \mathrm{cm}$ ), and brackish-saline groundwater $(\mathrm{EC}>3 \mathrm{mS} / \mathrm{cm})$; as already defined for the same area by Cozzolino et al. [13] and Giambastiani et al. [32,33]. Groundwater monitoring data (WTD and EC) and local lithological information $[13,32,33]$ were used to constraint the resistivity inversion and calibrate/validate the ERT surveys. The calibration was performed on the ERT profile 5 by simultaneously comparing groundwater data and resistivity values in proximity of the monitoring point (MLS3 in Figure 1). The validation was conducted for ERT profile 8 using a nearby groundwater monitoring point (MLS1 in Figure 1).

Climate data were downloaded from the Ravenna weather station (the closest to the study area) belonging to the ARPAE regional agency network. 


\section{Results and Discussion}

\subsection{Climate Data}

The Figure 3 shows that 2014 (year of field surveys) was the hottest year of the entire climate time series (1976-2017), but at the same time an average year in terms of total precipitation. The average annual temperature for 2014 was $15.5^{\circ} \mathrm{C}$ and the total precipitation was $750 \mathrm{~mm}$, slightly above the average annual precipitation for the station considered. Despite this, July 2014 was one of the wettest July months of the last decades, with over $100 \mathrm{~mm}$ of rainfall [44]. It is well documented that rainfall is the only source of water that can infiltrate into the phreatic aquifer and generate freshwater lenses [13,33]; in this regard, the annual precipitation that occurred in 2014 is not far from the average (Figure 3). There are no dry or wet extremes in 2014, supporting the assumption that our study was performed in typical climate conditions for the Ravenna coast.

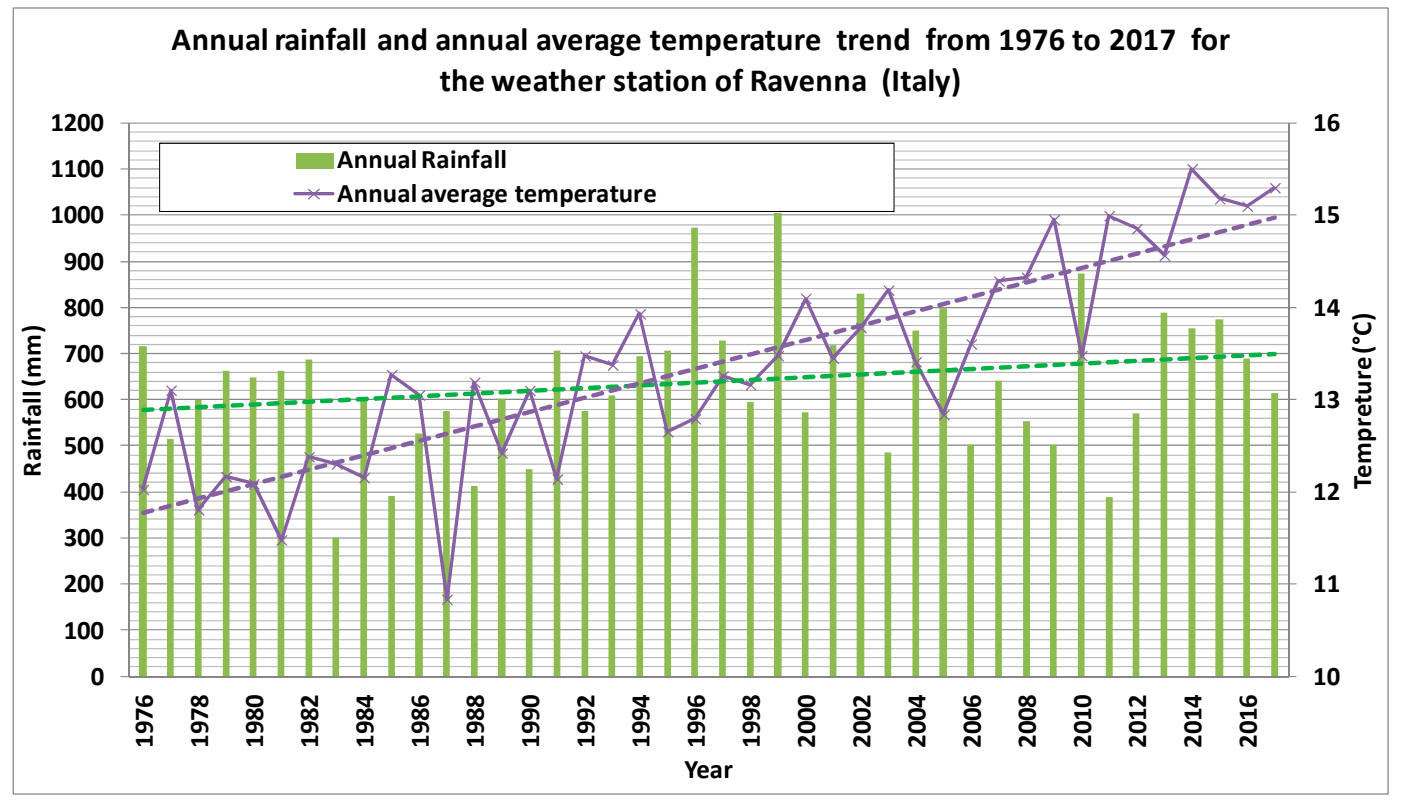

Figure 3. Annual rainfall and average temperature trend from 1976 to 2015 for the weather station of Ravenna (Italy).

\subsection{Calibration and Validation}

All eight ERT profiles extend for $48 \mathrm{~m}$ in the East-West direction covering the whole foredune extension (Figure 1 for the location). ERT profile 5 was the first profile acquired and it was used for the calibration of the subsurface resistivity model. After inversion, the model was compared to the vertical distribution of EC values and WTD collected in MLS3.

It is assumed that the investigated portion of the aquifer has a homogenous and isotropic distribution of hydraulic conductivity $(\mathrm{K})$. The lithology is of coarse to medium well-sorted sand, and thus changes in resistivity values are caused by changes in saturation and groundwater salinity. Based on both field data and the outcomes by Sabia et al. [45] at an adjacent site, four resistivity intervals $(\Omega \mathrm{m})$ were adopted to classify the hydrological units and are reported in Table 1.

Table 1. Resistivity intervals $(\Omega \mathrm{m})$ adopted to classify the hydrological units.

\begin{tabular}{ccc}
\hline $\begin{array}{c}>700 \Omega \mathrm{m} \\
700-300 \Omega \mathrm{m}\end{array}$ & $\begin{array}{c}\text { Unsaturated sand } \\
\text { Capillary fringe }\end{array}$ & $\begin{array}{c}\text { Unsaturated } \\
\text { zone }\end{array}$ \\
\hline $\begin{array}{c}300-30 \Omega \mathrm{m} \\
<30 \Omega \mathrm{m}\end{array}$ & $\begin{array}{c}\text { Freshwater } \\
\text { Brackish-saline groundwater }\end{array}$ & Saturated zone \\
\hline
\end{tabular}




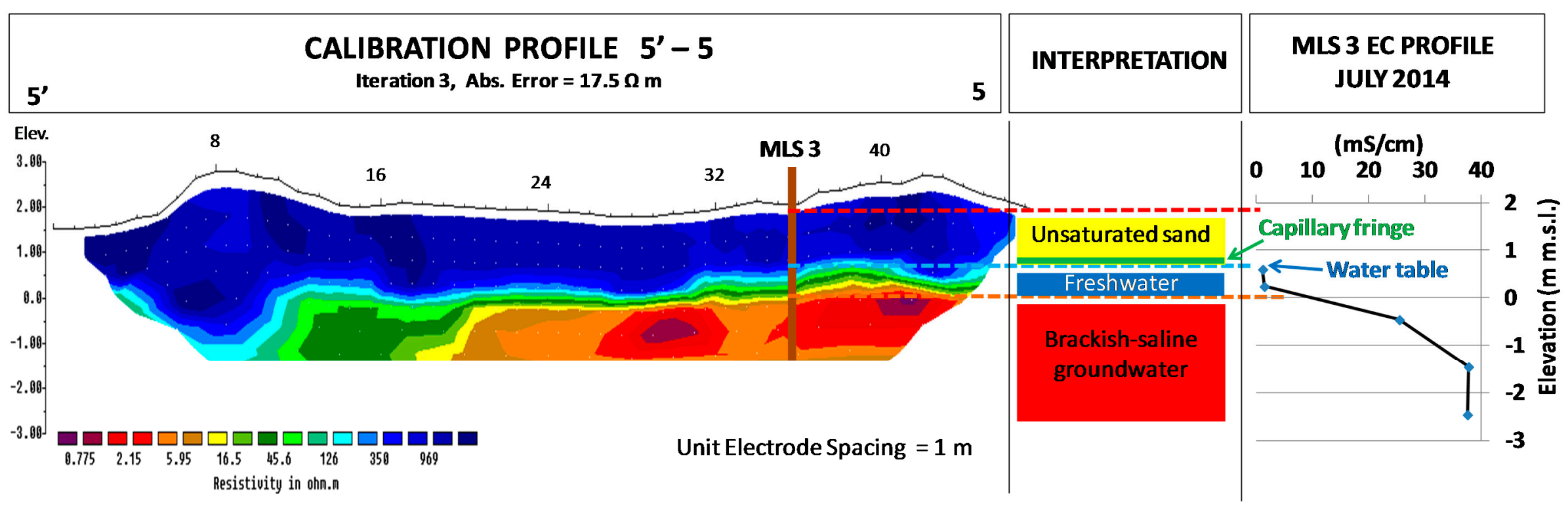

Figure 4. Inverted resistivity profile $5^{\prime}-5$. On the right side, the vertical EC profile of groundwater at MLS3 (water table depth (WTD) is shown by the green dashed line) and interpretation of the resistivity classes. 


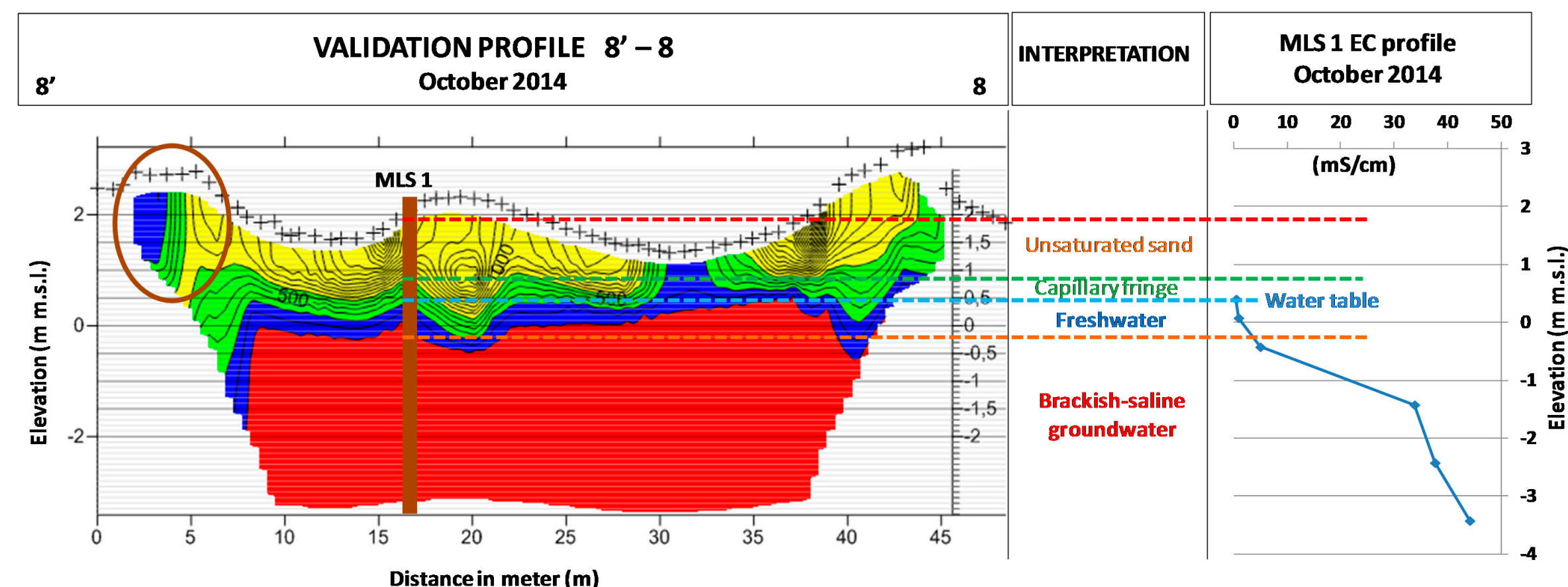

Figure 5. Subsurface model of profile 8'-8 where the four hydrogeological units are identified by different colors. The vertical log of groundwater EC data at MLS1 is shown on the right side of the figure (WTD is marked by the dashed light-blue line). Note that the brown-color circle indicates an abrupt change in resistivity due to the unpaved road. 
The calibration is reported graphically in Figure 4. The upper part of the inverted 2D model has a resistivity above $700 \Omega \mathrm{m}$, which is explained by the presence of unsaturated sand. The deepest part of the 2D model shows resistivity values below $30 \Omega \mathrm{m}$ and it is categorized as brackish-saline groundwater. The thin middle portion of the $2 \mathrm{D}$ model is characterized by a strong resistivity gradient from 30 to $700 \Omega \mathrm{m}$, which is interpreted as a freshwater lens topped by a capillary fringe. The $300 \Omega \mathrm{m}$ iso-resistivity contour was selected for distinguishing the unsaturated and saturated zones and identifying the WTD.

The inverted resistivity 2D model from the ERT profile 8 was validated by using groundwater data from MLS1 (Figure 5). The four selected hydrological units perfectly match the EC vertical log at MLS1. The WTD is also correctly identified from the ERT survey (Figure 5).

\subsection{Hydrological Unit Identification}

Due to space limitation, only two representative ERT profiles are reported in Figures 6 and 7, the remaining profiles are provided as Supplementary Material to this paper.

Based on the calibration and validation results presented above, Figures 6 and 7 show the subsurface models of profiles 2 and 9. Despite the fact that the ERT profiles sample only the uppermost portion of the phreatic coastal aquifer (maximum $-3 \mathrm{~m}$ m.s.l.), it is apparent that most of the investigated volume is saturated with brackish-saline groundwater. The same salinity distribution is present in all subsurface models elaborated in this study (see Supplementary Material). Many authors report the almost complete salinization of the shallow coastal aquifer. Giambastiani et al. [46] and Antonellini et al. [47] state that for a distance of 4-6 km from the Adriatic Sea, the presence of freshwater is sporadic and limited to small ephemeral lenses. Moving towards sea, Cozzolino et al. [13] and Giambastiani et al. [33] assessed the presence and dimensions of freshwater lenses by direct measurements concluding that thin freshwater lenses are permanently present only under coastal dunes and backdune systems. The ERT surveys carried out in this study confirm these direct measurements. All ERT surveys (see Supplementary Material), in fact, indicate the presence of freshwater lenses with a thickness of about $0.5 \mathrm{~m}$. In ERT profile 2 (Figure 6) an E-W continuous freshwater lens (blue color), about 0.5-m thick is recognized above the brackish-saline groundwater. In ERT profile 9 (Figure 6), on the other hand, the freshwater lens is thinner than the one at ERT profile 2. There is a discontinuity in this lens at the dune slack where elevated evaporation rates from a shallow water table lower the WTD and induce saltwater seepage from below [33]. This seepage phenomenon has been also recognized by Mollema et al. [48] and Vandenbohede et al. [49] in adjacent farmlands where shallow freshwater lens is threatened by seepage of salt water from below.

In summary, a thin and horizontally continuous freshwater lens is recognized in ERT profiles 1, 2, 3, 4 and 5, whereas ERT profiles 7, 8, and 9 show a discontinuous lens interrupted by saltwater seepage. The size and extension of freshwater lenses identified in this study agree with the findings of Cozzolino et al. [13] and Giambastiani et al. [33] for adjacent areas. The presence of these thin freshwater lenses in coastal environment dominated by saline groundwater enables the existence of particular ecosystems in an otherwise very saline environment $[4,50,51]$, nevertheless the stabilization of dunes [9]. Their limited extension and topography make them one of the most vulnerable aquifer systems in the world due to sea level rise and/or intensive anthropic exploitation [50].

The shorter, 0.5-m electrode spacing used for the ERT profile 9 required five lines of 32 electrodes to get the same spatial coverage of the other profiles $(48 \mathrm{~m})$ and thus more than double the time. The comparison with the inverted profile 8 (electrode spacing of $1 \mathrm{~m}$ and the same location; see Figure 1 ) indicates the same capability in hydrological unit identification. The shape and thickness of the identified unit are almost coincident (see Supplementary Material).

In ERT profiles 2 and 9, the unsaturated sand layer (about 1-m thick) is recognized at the top of the profiles. Both profiles show discontinuous unsaturated units with thickness less than $1 \mathrm{~m}$ in profile 2, and almost $2 \mathrm{~m}$ in profile 9. Overall, the unsaturated zones of ERT profiles 7, 1, and 2 are thinner than in profiles $3,4,5,8$, and 9 . The dune conservation state affects the vertical extension of the unsaturated sand: where the dune is well-preserved and with an high relief ( $>3 \mathrm{~m}$ m.s.l.; i.e., profiles 3 , 
4,5 , and 8) the unsaturated unit is almost 2-m thick, whereas if the dune is absent or limited in relief (profiles 7, 1, and 2), the unsaturated sand is thin and, therefore, the water table is shallow.

The presence of an unpaved road on the west side of all the ERT profiles generates a different sediment consolidation and consequently distortions to the 2D resistivity models (Figure 5). The transit of vehicles causes sediment compaction, decreasing the medium resistivity [52]. Based on this observation, the consistently lower resistivity values in correspondence of the road have to be considered as model artifacts and not as hydrological changes.

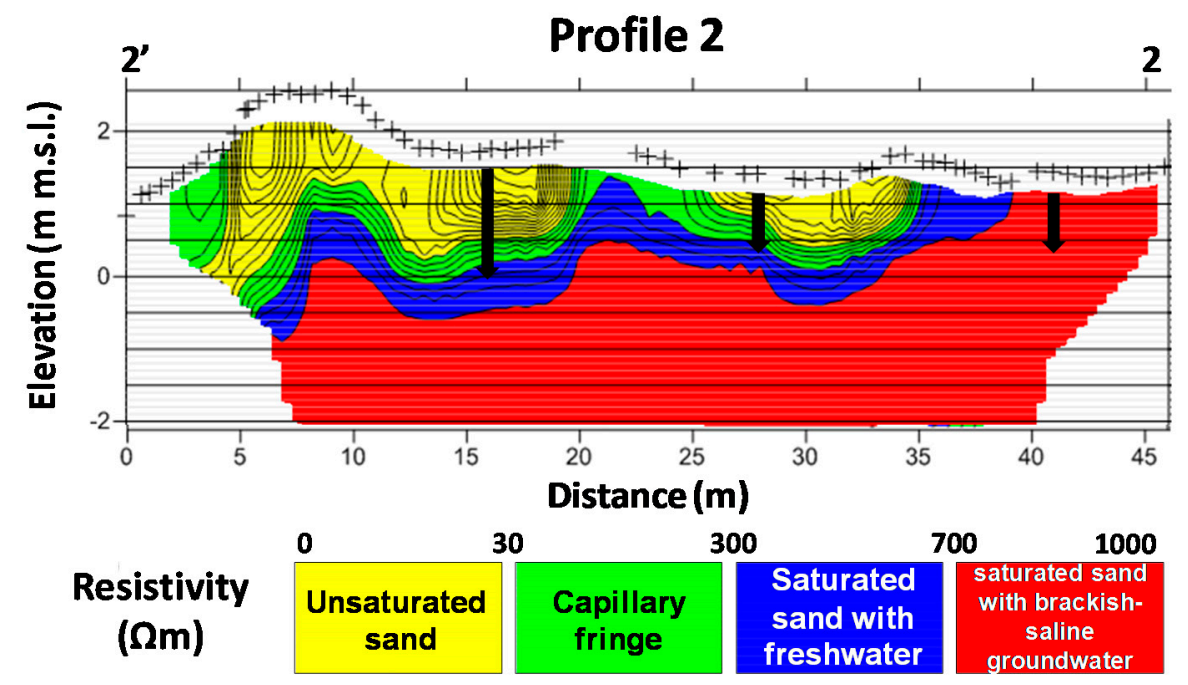

Figure 6. Subsurface model of profile 2'-2. Black arrows represent the auger holes location and the arrow head the measured WTD.

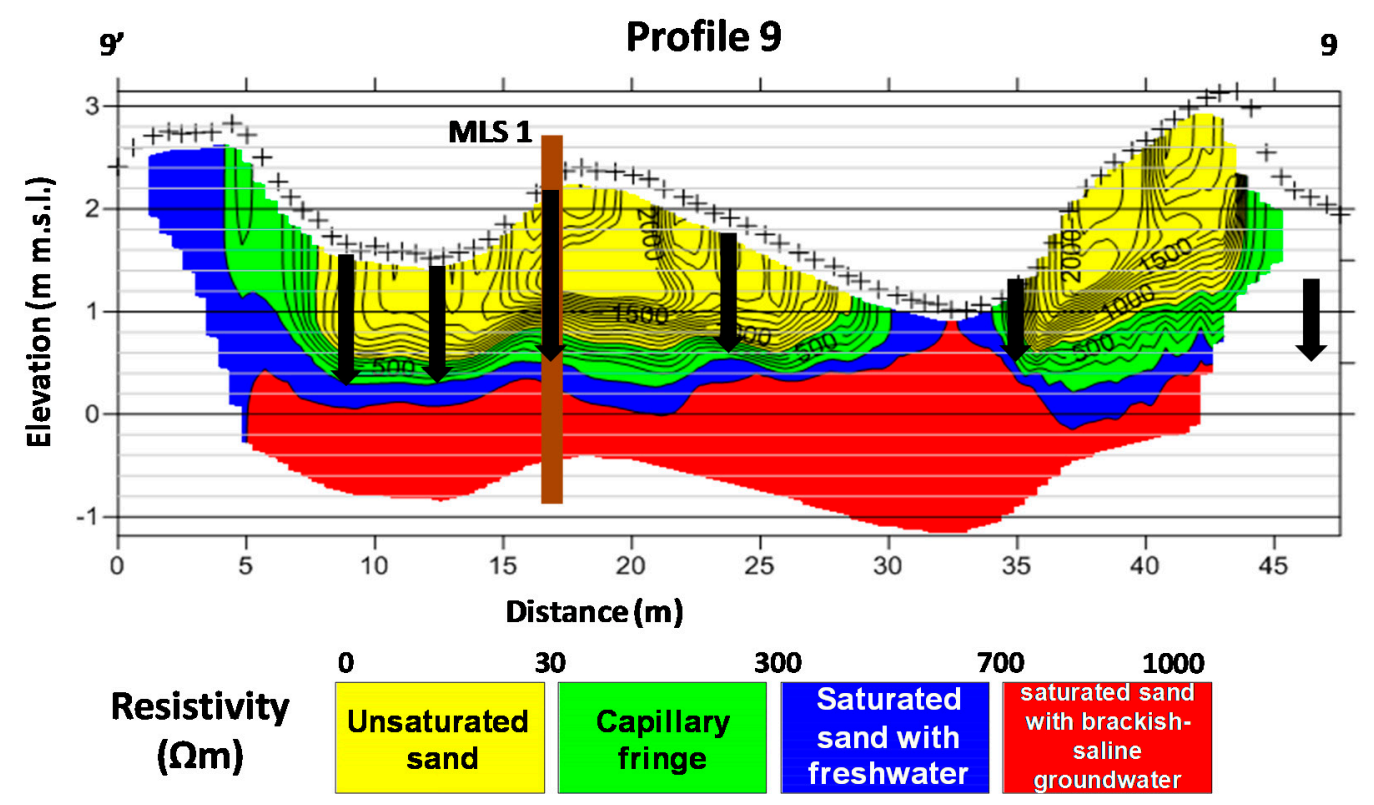

Figure 7. Subsurface model of profile 9'-9. Black arrows represent the auger holes location and the arrow head the measured WTD. In this case the electrode spacing is $0.5 \mathrm{~m}$ and the investigation depth is about $2-2.5 \mathrm{~m}$.

\subsection{WTD}

The WTD represented in the subsurface models by the uppermost boundary of the freshwater lens follows closely the surface topography. It usually ranges from $0.4-0.5 \mathrm{~m}$ m.s.l. seaward where 
high-relief dunes are present, to $0.0-0.2 \mathrm{~m}$ m.s.l. inland. The gradient is inland-oriented, because of the drainage rate controlled by the land reclamation authority [53].

The WTD and its landward gradient observed in this study are in agreement with the results of previous studies performed in the same area $[13,32,33]$. The WTD is controlled by the drainage channel, which crosses the pine forest parallel to the coastline. The drainage channel guarantees a 1-m-deep vadose zone that preserves the coastal forest from water logging and flooding $[4,33]$ but at the same time promotes saltwater seepage from the bottom of the aquifer $[49,53]$.

The comparison between profile 8 (1-m electrode spacing) and profile 9 (0.5-m electrode spacing) does not indicate any differences in hydrological units and WTD identification. The indirect WTD obtained by the two inverted models are equivalent and the inland gradient of the WTD is confirmed.

The models show some distortion with respect to the measured auger hole data in both the inland and the seaside borders of the ERT profiles; this is due to: the compaction of the material as described above for the inland border, and to high salt content in the unsaturated profile in the seaside border. An example is reported in profile 2 where the WTD extrapolated by the inverted model is at the surface at a distance of about $35 \mathrm{~m}$ from inland border (Figure 6), whereas the measured WTD in the same point (indicated by the black arrow in Figure 6) is a few centimeters above m.s.l. The same problem is also present in profile 1 (Supplementary Material) and it could be due to the abundance of salt periodically left in the sediment profile by the tide cycle: this salt concentration decreases the sediment resistivity.

\subsection{Effectiveness of the ERT}

The comparison between measured groundwater data (EC and WTD) and ERT data is listed in Table 2, while the correlation is shown in Figure 8. Out of a total of 27 available electrical conductivity measurements from auger holes, five are poorly attributed (for example extrapolated by ERT model as salt when it was measured fresh in the auger hole and vice versa), and 18 are correctly attributed, while the remaining four are impossible to compare because the auger hole was drilled out of the ERT model domain.

The WTD ranges from -0.2 to $0.6 \mathrm{~m}$ m.s.l. in the studied profiles. As shown in Figure 8, the data are well aligned along the correlation line and the $\mathrm{R}^{2}$ is equal to 0.75 , indicating good correlation. The error between direct and indirect WTD is $0.09 \mathrm{~m}$. Limiting to the profile 9 (0.5-m electrode spacing), the same error is calculated for the WTD determination.

The average absolute error of the inverted models is about $25 \Omega \mathrm{m}$, adopting the electrode spacing of $1 \mathrm{~m}$. The absolute error increase up to $30 \Omega \mathrm{m}$ for the electrode spacing of $0.5 \mathrm{~m}$. It seems to be rather large when compared to other ERT studies where the root mean square error was between 5 and 15\% [12,17-20]. In the relatively young investigated deposits of the Ravenna coastal zone, the presence of abundant buried driftwood within the dune body increases the probability of points with confused resistivity information. Despite this, the tested methodology with 1-m electrode spacing provides a detailed vertical resolution, which allows us to identify the unsaturated zone, the freshwater lens, and the brackish-saline saturated zone as well as the WTD with a discrepancy with respect to the measured depth of only $0.1 \mathrm{~m}$. The further reduction to $0.5-\mathrm{m}$ electrode spacing tested in profile 9 does not guarantee any benefits with respect to $1-\mathrm{m}$ spacing. On the contrary, it required double the time during field survey and the vertical investigated depth decreased from 4-5 m to only $2.5 \mathrm{~m}$. In the Ravenna hydrological setting with extremely shallow WTD, working at 2.5 investigated depth still allows for the observation of WTD and mixing zone, but in other contexts this vertical reduction could not guarantee the inclusion of the saturated zone. In light of this, an electrode spacing below $1 \mathrm{~m}$ is not recommended for similar hydrogeological studies. 
Table 2. Comparison between auger hole measured data and ERT data for all the investigated profiles. The red cells of the table represent poorly attributed EC by the ERT-inverted model; green cells represent correct EC attribution and yellow cells indicate no possible comparison.

\begin{tabular}{|c|c|c|c|c|c|c|}
\hline \multirow{2}{*}{ Profile } & \multirow{2}{*}{ Auger Hole } & \multicolumn{3}{|c|}{$\mathrm{EC}(\mathrm{mS} / \mathrm{cm})$} & \multicolumn{2}{|r|}{ WTD (m m.s.l.) } \\
\hline & & Auger & Hole & Computed ERT & Auger Hole & Computed ERT \\
\hline 7 & sea & 35.5 & Salty & Out of the ERT domain & 0.21 & Out of the ERT domain \\
\hline 7 & middle & 13.9 & Salty & Fresh & 0.44 & 0.4 \\
\hline 7 & inland & 6.5 & Salty & Salty & 0.49 & 0.5 \\
\hline 1 & sea & 36.2 & Salty & Salty & 0.3 & Bordering the ERT domain \\
\hline 1 & middle & 17.7 & Salty & Fresh & 0.47 & 0.4 \\
\hline 1 & inland & 4.5 & Salty & Fresh & 0.14 & 0.2 \\
\hline 2 & sea & 31.1 & Salty & Salty & 0.31 & Bordering the ERT domain \\
\hline 2 & middle & 3.8 & Fresh & Fresh & 0.39 & 0.3 \\
\hline 2 & inland & 2.4 & Fresh & Fresh & 0.01 & -0.1 \\
\hline 3 & sea & 9.3 & Salty & Out of the ERT domain & -0.05 & Out of the ERT domain \\
\hline 3 & middle & 0.6 & Fresh & Fresh & 0.35 & 0.3 \\
\hline 3 & inland & 0.9 & Fresh & Fresh & 0.06 & 0.3 \\
\hline 4 & sea & 7.6 & Salty & Fresh & -0.13 & -0.3 \\
\hline 4 & middle & 11.7 & Salty & Fresh & 0.37 & 0.1 \\
\hline 4 & inland & 0.8 & Fresh & Fresh & 0.08 & 0.0 \\
\hline 5 & sea & 10.3 & Salty & Out of the ERT domain & 0.07 & Out of the ERT domain \\
\hline 5 & middle & 0.4 & Fresh & Fresh & 0.28 & 0.3 \\
\hline 5 & inland & 0.7 & Fresh & Fresh & 0.06 & 0.1 \\
\hline 8 & sea & 0.6 & Fresh & Fresh & 0.56 & 0.7 \\
\hline 8 & middle & 0.3 & Fresh & Fresh & 0.32 & 0.4 \\
\hline 8 & inland & 0.3 & Fresh & Fresh & 0.31 & 0.3 \\
\hline 9 & sea & 6.8 & Salty & Out of the ERT domain & 0.516 & Out of the ERT domain \\
\hline 9 & middle & 0.5 & Fresh & Fresh & 0.532 & 0.4 \\
\hline 9 & middle & 0.5 & Fresh & Fresh & 0.458 & 0.5 \\
\hline 9 & middle & 0.6 & Fresh & Fresh & 0.57 & 0.5 \\
\hline 9 & middle & 0.4 & Fresh & Fresh & 0.419 & 0.3 \\
\hline 9 & inland & 0.5 & Fresh & Fresh & 0.397 & 0.3 \\
\hline
\end{tabular}

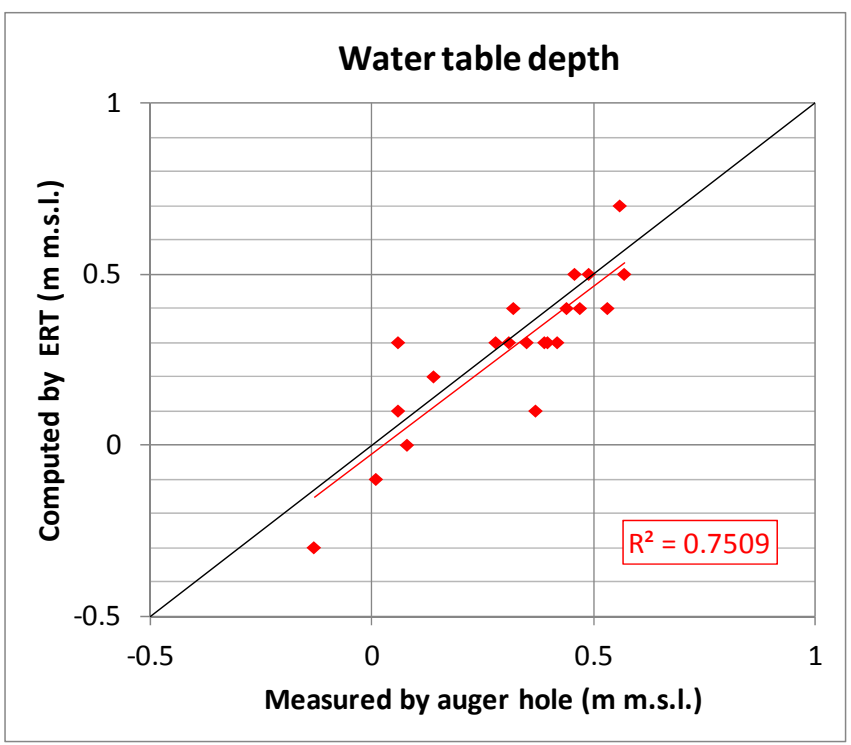

Figure 8. Scatter plot diagram between measured WTD (by auger holes) and computed data (by ERT inversion).

To the best of the authors' knowledge, this is the first study adopting ERT as a tool for freshwater lens identification and characterization. The methodology presented requires calibration and validation at a spatial scale similar to the vertical resolution of the ERT profile. This can be achieved by using high-resolution multi-level samplers for acquiring groundwater data to be used for calibration. In addition, for homogeneous lithological conditions such as the one investigated in this study, 
the detailed vertical resolution of ERT profiles could be used in the construction of reliable 3D models from a series of closely spaced 2D profiles. In this hypothesis, lines spacing and electrodes distance have to be comparable with the target dimensions [54]. As verified at a large scale by García-Menéndez et al. [20], this high resolution ERT could be effective for monitoring managed aquifer recharge (MAR) experiments or for observing in detailed channel-aquifer interactions within a salinized aquifer.

\section{Conclusions}

High-resolution (0.5-1 m) ERT calibrated on field data at the same vertical spatial resolution allows for the correct identification of thin ephemeral freshwater lenses in the pervasively salinized coastal aquifer of Ravenna. This is important to evaluate where these sparse and discontinuous lenses are located and how they vary in extension and thickness during the year. In fact, the presence of these limited freshwater lenses in coastal environments enables the existence of particular coastal ecosystems, although with the stabilization of dunes. The knowledge of their position and extension allows to focus preservation efforts and eventually plan MAR interventions.

Once calibrated, the methodology allows to acquire many profiles in a short time span, and hence to characterize large portions of a coastal aquifer that would be impractical to equip with a network of multi-level samplers or by expensive auger holes campaigns.

High-resolution ERT is reliable and repeatable in time, allowing for the acquisition of multiple profiles during the year in order to characterize the evolution of the freshwater lenses at a level not possible with other methodologies.

In the specific case of freshwater lenses with limited thickness $(<1 \mathrm{~m})$, an electrode spacing of $1 \mathrm{~m}$ guarantees the correct identification of the hydrological units, as demonstrated by the validation. The reduction to electrode spacing of $0.5 \mathrm{~m}$ does not lead to any further benefits and requires longer in-time field surveys and a decreased investigated depth.

The ERT methodology tested in this coastal setting may be appropriate also for other areas in the world where low coastal plains under intensive drainage are present and where the conservation of scarce freshwater resources is challenged by a lack of an extensive piezometer-based monitoring network.

Supplementary Materials: The following are available online at http:/ /www.mdpi.com/2073-4441/10/8/1067/ s1.

Author Contributions: The study is part of the master thesis conducted by C.A., under the supervision of M.A., and B.M.S.G., N.G., B.M.S.G., and N.G. collaborated with C.A. during ERT data acquisition and monitoring campaigns, while E.B. contributed to data elaboration, result analysis, and the writing of part of the first draft of the article. All authors contributed to the writing, editing, and review of the paper.

Funding: This research received no external funding.

Acknowledgments: This research was partially included in the RIGED-RA project "Restoration and management of coastal dunes in the Northern Adriatic Coast-Ravenna" (Scientific Coordinator, Giovanni Gabbianelli), funded by the Flaminia Foundation with the collaboration of the Ravenna Municipality (Italy) and the IGRG lab (Integrated Geosciences Research Group) of the University of Bologna. The authors would like to thank the Carabinieri for Biodiversity, Punta Marina Office, which permitted the access to the protected natural areas, where this study was carried out.

Conflicts of Interest: The authors declare no conflict of interest.

\section{References}

1. De Louw, P.G.B.; Eeman, S.; Oude Essink, G.H.P.; Vermue, E.; Post, V.E.A. Rainwater lens dynamics and mixing between infiltrating rainwater and upward saline groundwater seepage beneath a tile-drained agricultural field. J. Hydrol. 2013, 501, 133-145. [CrossRef]

2. Cellone, F.; Tosi, L.; Carol, E. Estimating the freshwater-lens reserve in the coastal plain of the middle Río de la Plata Estuary (Argentina). Sci. Total Environ. 2018, 630, 357-366. [CrossRef] [PubMed]

3. Custodio, E. Aquifères côtières de l'Europe: Une vision generale. Hydrogeol. J. 2010, 18, 269-280. [CrossRef]

4. Antonellini, M.; Mollema, P.N. Impact of groundwater salinity on vegetation species richness in the coastal pine forests and wetlands of Ravenna, Italy. Ecol. Eng. 2010, 36, 1201-1211. [CrossRef] 
5. Drabbe, J.; Ghijben, B.W. Nota in verband met de voorgenomen putboring nabij Amsterdam. Van Konink. Inst. Van Ing. 1889, 5, 8-22.

6. Herzberg, A. Die wasserversorgung einiger Nordseebader. J. Gasbeleucht. Wasserversorg. 1901, 44, 842-844.

7. De Louw, P.G.B.; Eeman, S.; Siemon, B.; Voortman, B.R.; Gunnink, J.; Van Baaren, E.S.; Oude Essink, G.H.P. Shallow rainwater lenses in deltaic areas with saline seepage. Hydrol. Earth Syst. Sci. 2011, 15, 3659-3678. [CrossRef]

8. Pinna, M.S.; Cogoni, D.; Fenu, G.; Bacchetta, G. The conservation status and anthropogenic impacts assessments of Mediterranean coastal dunes. Estuar. Coast. Shelf Sci. 2015, 167, 25-31. [CrossRef]

9. Olson, J.S. Lake Michigan dune development 2. Plants as agents and tools in geomorphology. J. Geol. 1958, 66, 345-351. [CrossRef]

10. Eeman, S.; Leijnse, A.; Raats, P.A.C.; van der Zee, S.E.A.T.M. Analysis of the thickness of a fresh water lens and of the transition zone between this lens and upwelling saline water. Adv. Water Resour. 2011, 34, $291-302$. [CrossRef]

11. Zarroca, M.; Bach, J.; Linares, R.; Pellicer, X.M. Electrical methods (VES and ERT) for identifying, mapping and monitoring different saline domains in a coastal plain region (Alt Empordà, Northern Spain). J. Hydrol. 2011, 409, 407-422. [CrossRef]

12. Tajul Baharuddin, M.F.; Othman, A.R.; Taib, S.; Hashim, R.; Zainal Abidin, M.H.; Radzuan, M.A. Evaluating freshwater lens morphology affected by seawater intrusion using chemistry-resistivity integrated technique: A case study of two different land covers in Carey Island, Malaysia. Environ. Earth Sci. 2013, 69, 2779-2797. [CrossRef]

13. Cozzolino, D.; Greggio, N.; Antonellini, M.; Giambastiani, B.M.S. Natural and anthropogenic factors affecting freshwater lenses in coastal dunes of the Adriatic coast. J. Hydrol. 2017, 551, 804-818. [CrossRef]

14. Oude Essink, G.H.P.; van Baaren, E.S.; de Louw, P.G.B. Effects of climate change on coastal groundwater systems: A modeling study in The Netherlands. Water Resour. Res. 2010, 46, 1-16. [CrossRef]

15. Balugani, E.; Antonellini, M. Measuring salinity within shallow piezometers: Comparison of two field methods. J. Water Resour. Prot. 2010, 2, 251. [CrossRef]

16. Land, L.A.; Lautier, J.C.; Wilson, N.C.; Chianese, G.; Webb, S. Geophysical Monitoring and Evaluation of Coastal Plain Aquifers. Ground Water 2004, 42, 59-67. [CrossRef] [PubMed]

17. Rey, J.; Martínez, J.; Barberá, G.G.; García-Aróstegui, J.L.; García-Pintado, J.; Martínez-Vicente, D. Geophysical characterization of the complex dynamics of groundwater and seawater exchange in a highly stressed aquifer system linked to a coastal lagoon (SE Spain). Environ. Earth Sci. 2013, 70, 2271-2282. [CrossRef]

18. Francés, A.P.; Ramalho, E.C.; Fernandes, J.; Groen, M.; Hugman, R.; Khalil, M.A.; De Plaen, J.; Monteiro Santos, F.A. Contributions de l'hydrogéophysique au modèle conceptuel hydrogéologique de l'aquifère côtier Albufeira-Riberia de Quarteira en Algarve, Portugal. Hydrogeol. J. 2015, 23, 1553-1572. [CrossRef]

19. Kazakis, N.; Pavlou, A.; Vargemezis, G.; Voudouris, K.S.; Soulios, G.; Pliakas, F.; Tsokas, G. Seawater intrusion mapping using electrical resistivity tomography and hydrochemical data. An application in the coastal area of eastern Thermaikos Gulf, Greece. Sci. Total Environ. 2016, 543, 373-387. [CrossRef] [PubMed]

20. García-menéndez, O.; Ballesteros, B.J.; Renau-Pruñonosa, A.; Morell, I.; Mochales, T.; Ibarra, P.I.; Rubio, F.M. Using electrical resistivity tomography to assess the effectiveness of managed aquifer recharge in a salinized coastal aquifer. Environ. Monit. Assess. 2018, 190, 100. [CrossRef] [PubMed]

21. Kumar, K.S.A.; Priju, C.P.; Prasad, N.B.N. Study on Saline Water Intrusion into the Shallow Coastal Aquifers of Periyar River Basin, Kerala Using Hydrochemical and Electrical Resistivity Methods. Aquat. Procedia 2015, 4, 32-40. [CrossRef]

22. Galazoulas, E.C.; Mertzanides, Y.C.; Petalas, C.P.; Kargiotis, E.K. Large Scale Electrical Resistivity Tomography Survey Correlated to Hydrogeological Data for Mapping Groundwater Salinization: A Case Study from a Multilayered Coastal Aquifer in Rhodope, Northeastern Greece. Environ. Process. 2015, 2, 19-35. [CrossRef]

23. Kirsch, R.; Yaramanci, U. Geoelectrical methods. In Groundwater Geophysics: A Tool for Hydrogeology; Kirsch, R., Ed.; Springer: Berlin/Heidelberg, Germany, 2009; pp. 85-117. ISBN 978-3-540-88405-7.

24. Wilkinson, P.B.; Meldrum, P.I.; Kuras, O.; Chambers, J.E.; Holyoake, S.J.; Ogilvy, R.D. High-resolution Electrical Resistivity Tomography monitoring of a tracer test in a confined aquifer. J. Appl. Geophys. 2010, 70, 268-276. [CrossRef] 
25. European Parliament. Directive 2009/147/EC of the European Parliament and of the Council of 30 November 2009 on the conservation of wild birds. Off. J. Eur. Union 2010, 32, 128-146.

26. The Council of the European Communities. Council Directive 92/43/EEC of 21 May 1992 on the conservation of natural habitats and of wild fauna and flora. Off. J. 1992, L 206, 7-50.

27. United Nations Educational, Scientific and Cultural Organization. The convention on wetlands of international importance especially as waterfowl habitat. Environ. Policy Law 1983, 996, 245. [CrossRef]

28. Teatini, P.; Ferronato, M.; Gambolati, G.; Bertoni, W.; Gonella, M. A century of land subsidence in Ravenna, Italy. Environ. Geol. 2005, 47, 831-846. [CrossRef]

29. Taramelli, A.; Di Matteo, L.; Ciavola, P.; Guadagnano, F.; Tolomei, C. Temporal evolution of patterns and processes related to subsidence of the coastal area surrounding the Bevano River mouth (Northern Adriatic) - Italy. Ocean Coast. Manag. 2015, 108, 74-88. [CrossRef]

30. Sytnik, O.; Stecchi, F. Disappearing coastal dunes: Tourism development and future challenges, a case-study from Ravenna, Italy. J. Coast. Conserv. 2015, 19, 715-727. [CrossRef]

31. Ciavola, P.; Armaroli, C.; Chiggiato, J.; Valentini, A.; Deserti, M.; Perini, L.; Luciani, P. Impact of storms along the coastline of Emilia-Romagna: The morphological signature on the Ravenna coastline (Italy). J. Coast. Res. 2007, 50, 1-5.

32. Giambastiani, B.M.S.; Colombani, N.; Greggio, N.; Antonellini, M.; Mastrocicco, M. Coastal aquifer response to extreme storm events in Emilia-Romagna, Italy. Hydrol. Process. 2017, 31, 1613-1621. [CrossRef]

33. Giambastiani, B.M.S.; Greggio, N.; Nobili, G.; Dinelli, E.; Antonellini, M. Forest fire effects on groundwater in a coastal aquifer (Ravenna, Italy). Hydrol. Process. 2018, 32, 2377-2389. [CrossRef]

34. Amorosi, A.; Colalongo, M.L.; Fiorini, F.; Fusco, F.; Pasini, G.; Vaiani, S.C.; Sarti, G. Palaeogeographic and palaeoclimatic evolution of the Po Plain from 150-ky core records. Glob. Planet. Chang. 2004, 40, 55-78. [CrossRef]

35. Amorosi, A.; Colalongo, M.L.; Pasini, G.; Preti, D. Sedimentary response to Late Quaternary sea-level changes in the Romagna coastal plain (northern Italy). Sedimentology 1999, 46, 99-121. [CrossRef]

36. Francés, A.P.; Su, Z.; Lubczynski, M.W. Integration of Hydrogeophysics and Remote Sensing with Coupled Hydrological Models. Ph.D. Thesis, University of Twente, Enschede, The Netherlands, 17 July 2015.

37. Warner, D.L. Preliminary field studies using earth resistivity measurements for delineating zones of contaminated ground water. Groundwater 1969, 7, 9-16. [CrossRef]

38. Geotomo Software. RES2DINV ver. 3.59 for Windows XP/Vista/7. Rapid 2-D resistivity and IP inversion using the least-squares method. In Geoelectrical Imaging 2D \& 3D; Geotomo Software: Penang, Malaysia, 2010.

39. DeGroot-Hedlin, C.; Constable, S. Occam's inversion to generate smooth, two-dimensional models from magnetotelluric data. Geophysics 1990, 55, 1613-1624. [CrossRef]

40. Batayneh, A.T. Use of electrical resistivity methods for detecting subsurface fresh and saline water and delineating their interfacial configuration: A case study of the eastern Dead Sea coastal aquifers, Jordan. Hydrogeol. J. 2006, 14, 1277-1283. [CrossRef]

41. Bauer, P.; Supper, R.; Zimmermann, S.; Kinzelbach, W. Geoelectrical imaging of groundwater salinization in the Okavango Delta, Botswana. J. Appl. Geophys. 2006, 60, 126-141. [CrossRef]

42. Sherif, M.; El Mahmoudi, A.; Garamoon, H.; Kacimov, A.; Akram, S.; Ebraheem, A.; Shetty, A. Geoelectrical and hydrogeochemical studies for delineating seawater intrusion in the outlet of Wadi Ham, UAE. Environ. Geol. 2006, 49, 536-551. [CrossRef]

43. Post, V.; Kooi, H.; Simmons, C. Using hydraulic head measurements in variable-density ground water flow analyses. Ground Water 2007, 45, 664-671. [CrossRef] [PubMed]

44. ARPAE Luglio 2014: Analisi di un'anomalia Meteorologica. Available online: https://www.arpae.it/ dettaglio_notizia.asp?id=5757\&idlivello=962 (accessed on 26 July 2018).

45. Sabia, M.; Antonellini, M.; Gabbianelli, G.; Giambastiani, B.; Lapenna, V.; Perrone, A.; Rizzo, E. Indagini geoelettriche per lo studio di strutture idrogeologiche nella Pineta di San Vitale (RA) [Geo-resistivity investigations for the characterization of hydrogeologic structures in the San Vitale Pine Forest (RA)]. In Proceedings of the Acta National Geophysical Meeting Solid Earth, Rome, Italy, 15-17 November 2005.

46. Giambastiani, B.M.S.; Antonellini, M.; Essink, G.H.P.O.; Stuurman, R.J. Saltwater intrusion in the unconfined coastal aquifer of Ravenna (Italy): A numerical model. J. Hydrol. 2007, 340, 91-104. [CrossRef] 
47. Antonellini, M.; Mollema, P.; Giambastiani, B.; Bishop, K.; Caruso, L.; Minchio, A.; Pellegrini, L.; Sabia, M.; Ulazzi, E.; Gabbianelli, G. Salt water intrusion in the coastal aquifer of the southern Po Plain, Italy. Hydrogeol. J. 2008, 16, 1541. [CrossRef]

48. Mollema, P.N.; Antonellini, M.; Dinelli, E.; Gabbianelli, G.; Greggio, N.; Stuyfzand, P.J. Hydrochemical and physical processes influencing salinization and freshening in Mediterranean low-lying coastal environments. Appl. Geochem. 2013, 34, 207-221. [CrossRef]

49. Vandenbohede, A.; Mollema, P.N.; Greggio, N.; Antonellini, M. Seasonal dynamic of a shallow freshwater lens due to irrigation in the coastal plain of Ravenna, Italy. Hydrogeol. J. 2014, 22, 893-909. [CrossRef]

50. Morgan, L.K.; Werner, A.D. Seawater intrusion vulnerability indicators for freshwater lenses in strip islands. J. Hydrol. 2014, 508, 322-327. [CrossRef]

51. Tanjal, C.; Carol, E.; Richiano, S.; Santucci, L. Freshwater lenses as ecological and population sustenance, case study in the coastal wetland of Samborombón Bay (Argentina). Mar. Pollut. Bull. 2017, 122, 426-431. [CrossRef] [PubMed]

52. Samouëlian, A.; Cousin, I.; Tabbagh, A.; Bruand, A.; Richard, G. Electrical resistivity survey in soil science: A review. Soil Tillage Res. 2005, 83, 173-193. [CrossRef]

53. Antonellini, M.; Allen, D.M.; Mollema, P.N.; Capo, D.; Greggio, N. Groundwater freshening following coastal progradation and land reclamation of the Po Plain, Italy. Hydrogeol. J. 2015, 23, 1009-1026. [CrossRef]

54. Negri, S.; Leucci, G.; Mazzone, F. High resolution 3D ERT to help GPR data interpretation for researching archaeological items in a geologically complex subsurface. J. Appl. Geophys. 2008, 65, 111-120. [CrossRef]

(C) 2018 by the authors. Licensee MDPI, Basel, Switzerland. This article is an open access article distributed under the terms and conditions of the Creative Commons Attribution (CC BY) license (http:/ / creativecommons.org/licenses/by/4.0/). 